\title{
Herpes zoster in frail elderly patients: prevalence, impact, management, and preventive strategies
}

Ermanno Zorzoli, 1

Francesca Pica, 2

Giulia Masetti, 3

Elisabetta Franco, 4

Antonio Volpi, 5

Giovanni Gabutti, 6

Phone +390532455568

Email giovanni.gabutti@unife.it

1 Postgraduate School of Hygiene and Preventive Medicine, University of Rome Tor Vergata, Rome, Italy

2 Department of Experimental Medicine and Surgery, University of Rome Tor Vergata, Rome, Italy

3 Postgraduate School of Hygiene and Preventive Medicine, University of Ferrara, Ferrara, Italy

4 Department of Biomedicine and Prevention, University of Rome Tor Vergata, Rome, Italy

5 Our Lady of Good Counsel University, Tirana, Albania

6 Department of Medical Sciences, University of Ferrara, via Fossato di Mortara 64, 44121 Ferrara, Italy

Received: 2 February 2018 / Accepted: 20 April 2018

\section{Abstract}


Population aging is a worldwide phenomenon with significant and manifold impacts on society. Advanced age correlates with the onset of frailty. In this vulnerable state, the immune response is weakened and a higher susceptibility to infectious diseases is observed. The present narrative review aims to cover the topic of herpes zoster (HZ) and its complications in frail populations. The lifetime risk of developing $\mathrm{HZ}$ is estimated at about $20-30 \%$, and the risk increases with age. In older people, $\mathrm{HZ}$ can lead to the inability to recover the lifestyle, the interests, and the level of activity that existed before its development. Severity of the disease at presentation and depression are the major correlates of pain burden in patients with acute $\mathrm{HZ}$ and postherpetic neuralgia (PHN). The frail elderly need careful assessment prior to treatment initiation and could be affected to a greater extent by treatment-related adverse events. In light of the significant burden caused by HZ and its complications in the frail elderly, the adoption of a preventive strategy appears to be promising, particularly using vaccination in appropriate ageand risk-groups. Although very few vaccine studies consider explicitly the frail elderly as their study population, there is evidence that the live, attenuated vaccine induces significant immunological responses. An adjuvanted recombinant subunit vaccine has recently been approved in Canada, in the United States, in the European Union, and in Japan, and will likely provide additional opportunities for prevention.

AQ1

\section{Keywords}

Herpes zoster

Frailty

Elderly

Treatment

Prevention

Epidemiology

\section{Introduction}

Population aging is a worldwide phenomenon with significant and manifold impacts on society.

In $2017,13 \%$ of the global population was represented by people over 60 years old. Current estimates indicate that, in 2050, in most of the world's regions, 
with the exception of the African continent, about a quarter of the population will be aged $\geq 60$ years and the $\geq 80$-year-old population will treble [1].

Advanced age correlates with the onset of frailty: a condition that still lacks a standard definition. Frailty is commonly defined as a clinically identifiable state of vulnerability associated with the age-related decline of the functions and reserves of various physiological systems. It is important to highlight at this point that co/multi-morbidity and disability, though related to frailty and sometimes overlapping with it, represent distinct concepts [2]. There are currently two general models that try to describe and explain the features of frailty: the phenotype model [3] and the cumulative deficit model [4].

In the phenotype model, frailty is defined according to clinically observable traits that, if present, are predictive of a poorer outcome; specifically, the frailty syndrome (phenotype) is established when $\geq 3$ of these criteria are fulfilled: unintentional weight loss ( $>4.5 \mathrm{Kg}$ in the previous year), self-reported exhaustion, weakness (grip strength), slow walking speed, and low physical activity [3].

In the cumulative deficit model, the clinical deficits associated with aging (which can be symptoms, signs, abnormal test results, or diseases) are counted for an individual. More commonly in clinical practice, a concise Clinical Frailty Scale is constructed (ranging for example from Very Fit to Severely Frail), that allows for the existence of frailty over a spectrum, which is more in line with common clinical experience $[4,5,6]$.

According to a holistic view of the individual, frailty is "a dynamic state affecting an individual who experiences losses in one or more domains of human functioning (physical, psychological, and social), which is caused by the influence of a range of variables and which increases the risk of adverse outcomes" [7].

As previously mentioned, the prevalence of frailty increases with age and, according to a recent study, is about $10 \%$ in people aged $>65$ years, reaching between 25 and $50 \%$ in persons aged $>85$ years [8].

Among the several avenues of research in this area, one of particular interest $\mathrm{s}$ Please, delete the letter $\mathrm{s}$ is the potential role of age-induced modifications of the immune-endocrine axis in determining frailty. Studies have investigated the interlinked phenomena of sarcopenia, immune senescence, and 
chronic inflammation in aging ("inflammageing"), finding alterations in blood hormone concentrations [for example, lower levels of dehydroepiandrosterone sulphate (DHEAS) and a higher cortisol:DHEAS ratio] and in both the innate and adaptive branches of the immune system at cellular and molecular (cytokines) levels $[9,10,11]$.

This state of immunosenescence causes a higher susceptibility to infectious diseases [12].

Therefore, it is not surprising to find that the association between infectious agents and frailty has been investigated in several studies. In particular, herpesviruses, with their ability to establish lifelong latent infections with possible reactivations [13], have been studied for possible associations with frailty. Such studies have yielded conflicting results, with associations sometimes found between cytomegalovirus (CMV) antibodies and frailty, whereas antibodies against varicella zoster virus (VZV), Epstein-Barr Virus (EBV), and herpes simplex virus 1 and 2 (HSV-1 and HSV-2) were not associated with risks of incident frailty $[14,15,16]$. Considering the relevance of cell-mediated immunity (CMI) in the immune response to these viruses, measurement of antibodies might not be the most appropriate marker for investigating such associations $[17,18]$.

The drop in CMI that occurs with advancing age correlates with the incidence/onset of herpes zoster (HZ) and, especially in the over $50 \mathrm{~s}$, with both incidence and severity of $\operatorname{HZ}[19,20]$.

In light of the above considerations, the occurrence of HZ in frail elderly individuals will become more prevalent in the future with its attendant problems of care, long-term complications, and prevention [21,22].

The World Health Organization (WHO) promotes active aging as a way to optimize opportunities for health, participation, and security, to Please change as follows:

in order to improve.... improve the quality of life of the elderly [23].

Among currently available preventive measures, vaccination certainly plays an important role in promoting active and healthy aging [24].

In the present narrative review, we aim to cover the topic of $\mathrm{HZ}$ (and its complications) in frail populations in terms of epidemiology, impact, clinical 
management, and preventive measures.

Varicella zoster virus (VZV) is an alpha herpesvirus, with human hosts as its exclusive reservoir, transmitted through the airborne route and through direct contact with lesions. Primary VZV infection causes varicella (chickenpox) following which the virus remains in a latent state within cranial or spinal nervous ganglia for years/decades [25].

$\mathrm{HZ}$ is a disorder involving the sensory ganglion, nerves, and skin, that is caused by the reactivation of VZV [26, 27].

$\mathrm{HZ}$ appears in the form of an often severe and painful rash, which typically resolves within 1 month of presentation. However, about $20 \%$ of the affected individuals will continue to experience pain in the area of the rash, also after resolution, developing postherpetic neuralgia (PHN) [28].

PHN is a common and much feared complication of HZ, usually defined as pain that persists for over 90 days following the onset of the herpetic rash. PHN can last for months or years, and have a significant impact on the quality of life of affected individuals [29]. In a study performed in Italy on immune competent individuals 50 years and older diagnosed with $\mathrm{HZ}, 89.6 \%$ of patients reported $\mathrm{HZ}$-associated pain at the first medical examination [30]. Following a systematic review, the risk of developing PHN is variable (5-30\%) due to different study design, definition of $\mathrm{PHN}$, and population age. According to some studies, about $30-50 \%$ of patients that develop PHN will experience pain for more than a year [31].

Pain intensity at the rash onset, age, rash severity, length of prodromal pain, and cranial localization are more frequently reported as predictors of PHN, although it is unclear whether one or all of these factors are equally relevant $[28,32,33$, $34,35]$. PHN can become a severe and debilitating condition affecting all aspects of a patient's life and placing an economic and social burden on patients' caregivers [36, 37].

\section{Epidemiology and impact}

In the prevaccine era, in temperate-climate regions, fewer than $5 \%$ of adults were still susceptible to primary infection with VZV (varicella), that was usually acquired before adolescence. In tropical-climate regions, VZV is more commonly acquired among adolescents and adults [38]. 
The lifetime risk of developing $\mathrm{HZ}$ is estimated at about 20-30\% [39] and increases with age, such that $50 \%$ of the 85 years old population is expected to develop an episode of HZ [38]. Despite the fact that age is the most important risk factor for the occurrence of $\mathrm{HZ}$ and that $90 \%$ of affected patients are immunocompetent [30], disease- or treatment-related immunodepression can increase the risk of developing HZ [39].

Incidence rates of $\mathrm{HZ}$ in Europe, Asia-Pacific, and North America vary between 3 and 5/1000 person-years. At 60 years of age, the incidence rates are between 6 and 8/1,000 person-years and reach up to $8-12 / 1,000$ person-years at 80 years of age. Available data for Asia, Africa, and Latin America are limited; it is likely that HZ is not currently perceived as a health priority in these regions, but, in the future, the proportion of elderly people living in those areas will increase with a concomitant increase of HZ cases [31].

In Europe, $1.7 \pm 0.1$ million new cases are estimated to occur every year. Considering different age groups, the following incidence rates can be observed: 1/1,000 in children under 10 years, 2/1,000 in adults under 40 years, $1-4 / 1000$ in adults between 40 and 50 years, up to 7-8/1,000 after 50 years, and $10 / 1,000$ in the over 80 years [40].

A recent study performed in the Japanese population, which has the highest percentage of elderly individuals in the world, showed that the incidence rate in individuals over 60 years and in the over 80 years is comparable to the worldwide rate in the same age groups and that women are affected to a higher extent $(60.2 \%$ of cases $)$ [41].

Recent Italian data show an overall population rate of 6.4 cases/1000 personyears and a rising incidence rate with advancing age [42], thus confirming the observations from the previous studies [43].

The HEROES study analyzed the onset and persistence of pain in 413 immunocompetent patients over 50 years of age with a new diagnosis of HZ. Pain was reported by patients (89.6\%) and then measured with a Visual Analog Scale (VAS) score (mean score 5.8). Among patients who completed the 3month visit, 20.6\% showed pain, thus fulfilling all the criteria that define PHN (mean VAS score 3.7). The percentage of patients with PHN increases with age. Predictive factors for the development of PHN were found to be the presence of 
a high number of vesicles ( $\geq 50$ ), male sex, and a VAS score $\geq 3$ [30]. Such a level of pain intensity is considered to be related to interference in Activities of Daily Life (ADLs). A subsequent analysis of the whole sample, showed that $73 \%$ of patients with a new diagnosis of $\mathrm{HZ}$ had comorbidities and $69 \%$ were over 65 years of age. The most frequent comorbidities were cardiovascular diseases $(75 \%)$, diabetes $(24 \%)$, and respiratory diseases $(17 \%)$. The presence of pain at 3-month visit was significantly higher in patients with underlying conditions. Allodynia, paresthesia, pruritus, and VAS $\geq 3$ were also more common in these patients [44].

Possible risks for people with $\mathrm{HZ}$ are ischemic events such as Transient Ischemic Attacks (TIAs), stroke, and myocardial infarction; these conditions are related to the systemic inflammatory state triggered by the virus, which also affects vascular structures with the possibility of inducing endothelial damage and thrombosis [45].

The risk of stroke is higher in the first month after the episode of HZ [relative risk $\mathrm{RR}=1.78(95 \%$ CI 1.70-1.88) $]$ and tends to diminish with time. It is higher in cases of herpes zoster ophthalmicus (HZO) $[\mathrm{RR}=2.05$ (95\% CI 1.82-2.31)] in the first month after the episode), since ocular involvement is more frequently associated with inflammation of cerebral blood vessels [46].

In older people, $\mathrm{HZ}$ can lead to a permanent drop of the ability to be independent and to the inability to recover preHZ lifestyle, interests, and level of activity. When pain persists in the form of PHN, the negative effect on the life of patients affects not only the physical, but also the social and psychological domains with an impact on spouses and relatives [37]. The most frequently affected daily activity in patients with $\mathrm{HZ}$ or PHN is sleep, whereas psychological manifestations include stress, anxiety, and depressive symptoms. Consequences in the family environment and in the social sphere affect over $50 \%$ of individuals with $\mathrm{HZ}$ and $81 \%$ of individuals with PHN [47]. A study showed that $20 \%$ of people surveyed claimed to be isolated from their family and friends, while they were affected with HZ or PHN, with a resultant reduction in communication in 19 and $27 \%$ of cases, respectively [48].

Besides affecting the quality of life of patients, $\mathrm{HZ}$ also has a strong impact on health care systems.

Hospitalization rates for HZ, considering the overall population, vary between 2 and 25/100,000 person-years [31]. 
Hospitalization rates are higher in the older age groups; in USA, the rate varies from $10.2 / 100,000$ in the $60-69$ age group to $65.1 / 100,000$ in the over $80 \mathrm{~s}$ [49].

Following a systematic review of the relevant literature, the costs per hospitalized HZ case in Europe, USA, and Asia were estimated at 774.66$31,026.22 €, 9,041.36-23,219.82 €$, and 118.13-707.23 $€$, respectively; a hospitalized PHN case in Europe has an average cost of 4,026.05 $€$, whereas in USA, the cost is estimated to be between $1,538.17 €$ and $3,130.88 €$. The observed variation between different world areas is not due to epidemiological differences but to factors such as the socioeconomic development level and the type of health care system of the selected country [50].

Data from England from 2004 to 2013 report a yearly average rate of $8.8 / 100,000$ hospital admissions and confirm a high prevalence $(71.5 \%)$ in individuals $\geq 60$ years old (incidence of $28.4 / 100,000$ ). Overall, $82 \%$ of cases occur in immunocompetent people and hospitalizations are more common in women. The yearly average number of days of hospitalization and the related cost stand at 41,780 days and 13 million $£$, respectively [51].

A recent Italian study analyzed data about hospital admissions from the period 2001-2013. The general hospitalization rate was 12.1/100,000 inhabitants/year with a decreasing temporal trend, from $16.5 / 100,000$ in 2001 to $8.9 / 100,000$ in 2013. The number of hospitalization increased with age [52]. For more details, see Table 1. The total economic impact of $\mathrm{HZ}$ and PHN in immunocompetent individuals $>50$ years of age in Italy amounted to 41.2 million euros, of which at least a third was attributable to indirect costs related to productivity loss [43].

\section{Table 1}

Data from Italian study on hospitalization for HZ (2001-2013) [52]

\begin{tabular}{|l|l|}
\hline Hospital admission (total number) & 93,808 \\
\hline PHN-associated hospitalizations & 6,580 \\
\hline Yearly average number of hospital admissions & 6,391 \\
\hline \begin{tabular}{l} 
Type of population \\
\hline Gender (\%)
\end{tabular} \\
\hline Male & 45.1 \\
\hline Female & 54.9 \\
\hline
\end{tabular}


Hospitalization for age class (\%)

\begin{tabular}{|c|c|}
\hline$<49$ & 16.1 \\
\hline $50-69$ & 27.6 \\
\hline$>70$ & 56.3 \\
\hline Patient with a comorbidity (\%) & 32.5 \\
\hline
\end{tabular}

\section{Management}

Severity of the disease at presentation and depression are the major correlates of pain burden in patients with acute $\mathrm{HZ}$ and $\mathrm{PHN}[33,34,53]$.

The duration of $\mathrm{HZ}$ pain varies considerably, ranging from no pain or pain that lasts for only a few days after rash onset to pain that lasts for years after rash healing [26].

It is important to note that the frail elderly need careful assessment prior to treatment initiation and that they could be affected to a greater extent than "normal" adults by treatment-related adverse events, both in terms of frequency and in the possible severity of outcomes. More specifically, in the event of renal impairment, which is a frequent occurrence in the frail elderly, dosage has to be adjusted depending on creatinine clearance and adequate hydration needs to be ensured (another common problem in the frail elderly whose thirst reflex is diminished). The risk of neurological adverse events (such as headache, dizziness, confusion, tremor, convulsions, etc.) is also increased and their consequences can be serious, leading, for example, to falls with a high risk of fractures potentially leading to a vicious cycle of worsening frailty [54].

\section{Acute phase management of $\mathrm{HZ}$}

\section{Antiviral treatment}

In HZ patients, antiviral drugs accelerate the resolution of skin lesions and acute pain, and reduce the duration of chronic pain. Table 2 summarizes the doses, side effects, and contraindications of the drugs currently available for the management of acute $\mathrm{HZ}$ in adults. Acyclovir was the first oral antiviral therapy to be investigated for treatment; it decreases virus shedding and new lesion formation, accelerates healing, and decreases acute pain if started within 48$72 \mathrm{~h}$ of rash onset and given for 7 days. Valacyclovir, famciclovir, and brivudin 
are superior to acyclovir for the treatment of HZ, and have the advantage of simpler dosing regimens. The latter is not licensed in North America and its use requires caution as it is contraindicated in patients treated with 5-

fluoropyrimidines (5-FPs) and substances that are converted by the body to 5 FPs (such as, for example, cancer treatment regimens with 5-fluorouracil or substances converted to 5-fluorouracil). Famciclovir is comparable with valacyclovir, but the suggested doses vary widely in different countries [55].

\section{Table 2}

Dosages of drugs currently available for management of acute HZ in adults with normal renal function [55]

\begin{tabular}{|c|c|c|}
\hline Drug & Dosage & $\begin{array}{l}\text { Adverse events, contraindications, and } \\
\text { comments }\end{array}$ \\
\hline $\begin{array}{l}\text { Oral } \\
\text { aciclovir }\end{array}$ & $\begin{array}{l}800 \mathrm{mg}, \text { five times } \\
\text { daily for } 7 \text { days }\end{array}$ & $\begin{array}{l}\text { Nausea } / \text { vomiting }<3 \% \text {, diarrhea }<3 \% \text {, and } \\
\text { headache }<3 \% \text {. Similar to placebo rates }\end{array}$ \\
\hline $\begin{array}{l}\text { Intravenous } \\
\text { (IV) } \\
\text { aciclovir }\end{array}$ & $\begin{array}{l}5 \mathrm{mg} / \mathrm{kg} \text {, three times } \\
\text { daily } \\
10 \mathrm{mg} / \mathrm{kg} \text {, three times } \\
\text { daily in the } \\
\text { immunocompromised } \\
\text { and in cases of } \\
\text { encephalitis }\end{array}$ & $\begin{array}{l}\text { Rapid IV infusion is not recommended as } \\
\text { renal dysfunction may occur } \\
\text { Uncommon, usually reversible CNS } \\
\text { disturbances (agitation, disorientation, } \\
\text { tremors, etc.) may occur especially in } \\
\text { elderly patients and/or patients with renal } \\
\text { failure }\end{array}$ \\
\hline $\begin{array}{l}\text { Oral } \\
\text { brivudin }\end{array}$ & $\begin{array}{l}125 \mathrm{mg} \text {, once daily } \\
\text { for } 7 \text { days }\end{array}$ & $\begin{array}{l}\text { Nausea/vomiting } 1.2-2.6 \% \text {, vomiting } 0.5- \\
1.0 \% \text {, headache } 1.0-1.5 \% \text {. Similar to } \\
\text { placebo rates } \\
\text { Contraindicated in case of administration } \\
\text { of 5-FU (or similar drugs) within the } \\
\text { previous } 4 \text { weeks because of blockade of } \\
5 \text {-FU (or similar drugs) metabolism } \\
\text { resulting in dangerous and potentially fatal } \\
5-\text { FU toxicity } \\
\text { Adjustments in case of renal or liver } \\
\text { failure are not needed }\end{array}$ \\
\hline $\begin{array}{l}\text { Oral } \\
\text { valaciclovir }\end{array}$ & $\begin{array}{l}1000 \mathrm{mg} \text {, three times } \\
\text { daily for } 7 \text { days }\end{array}$ & $\begin{array}{l}\text { Nausea } 6-15 \% \text {, vomiting } 1-5 \% \text {, headache } \\
12-28 \% \text {. Similar to placebo rates }\end{array}$ \\
\hline $\begin{array}{l}\text { Oral } \\
\text { famciclovir }\end{array}$ & $\begin{array}{l}\text { Dose varies between } \\
\text { different countries } \\
500 \mathrm{mg} \text { three times } \\
\text { daily (USA and } \\
\text { Canada) } \\
250 \mathrm{mg} \text { three times } \\
\text { daily (Europe and } \\
\text { Australia) } \\
750 \mathrm{mg} \text { once daily } \\
\text { (UK, Spain, Ireland, } \\
\text { South Korea) } \\
\text { All the above refer to }\end{array}$ & $\begin{array}{l}\text { Nausea } 7-12 \% \text {, vomiting } 1-5 \% \text {, headache } \\
22-39 \% \text {. Similar to placebo rates }\end{array}$ \\
\hline
\end{tabular}


Analgesic treatment

There is no published evidence base for the optimal treatment of acute pain in $\mathrm{HZ}$, but combining antiviral therapy with additional effective relief of acute pain is indicated from a clinical viewpoint (Table 3 ).

Table 3

Treatment plan for pain associated with herpes zoster

\begin{tabular}{|c|c|c|}
\hline \multirow[t]{2}{*}{ Prevention of varicella } & Varicella vaccination & As child \\
\hline & & 'Catch-up' as adult \\
\hline \multirow[t]{2}{*}{$\begin{array}{l}\text { Prevention of herpes } \\
\text { zoster and PHN }\end{array}$} & Herpes zoster vaccination & Age $\geq 50$ \\
\hline & & Immunocompetent \\
\hline \multirow[t]{4}{*}{$\begin{array}{l}\text { Management of herpes } \\
\text { zoster }\end{array}$} & Psychosocial support & \\
\hline & Prompt antiviral drug treatment & Table 2 \\
\hline & Analgesia & $\begin{array}{l}\text { Paracetamol, } \\
\text { NSAID }\end{array}$ \\
\hline & Early neuropathic pain treatment & $\begin{array}{l}\text { e.g. TCA, opioid or } \\
\alpha 2 \delta \text { ligand }\end{array}$ \\
\hline \multirow[t]{9}{*}{$\begin{array}{l}\text { Management of } \\
\text { postherpetic neuralgia }\end{array}$} & $\begin{array}{l}\text { Tricyclic antidepressant drugs } \\
\text { (TCA) }\end{array}$ & Nortriptyline \\
\hline & & Amitriptyline \\
\hline & & Desipramine \\
\hline & $\begin{array}{l}\text { Reuptake inhibitor of serotonin } \\
\text { and norepinephrine }\end{array}$ & Duloxetine \\
\hline & Anticonvulsants ( $\alpha 2 \delta$ ligands) & Pregabalin \\
\hline & & Gabapentin \\
\hline & Opioids & Tramadol \\
\hline & & Oxycodone \\
\hline & & Morphine \\
\hline
\end{tabular}




\begin{tabular}{|l|l|l|}
\hline Topical agents & Lidocaine \\
\hline & Combinations & Capsaicin \\
\hline & $\begin{array}{l}\text { TCA + topical } \\
\text { topical }\end{array}$ \\
\hline & Opioid + topical \\
\hline & $\begin{array}{l}\text { Opioid }+\alpha 2 \delta \\
\text { ligand }\end{array}$ \\
\hline & $\begin{array}{l}\text { Opioid }+\alpha 2 \delta \\
\text { ligand }+ \text { topical }\end{array}$ \\
\hline
\end{tabular}

\section{Selected Complications other than PHN Please, this part} should be written using the same size font of previous parts (Antiviral treatment, Analgesic treatment)

The most frequent complications of $\mathrm{HZ}$ are listed in Table 4 [56]. The incidence and burden of complications other than PHN have not been widely studied, but ocular diseases and facial palsy seem to be the most frequent HZ-related complications in several studies worldwide, although with different frequencies $[57,58]$.

Table 4

Complications of herpes zoster [56]

\begin{tabular}{|l|l|l|l|}
\hline Cutaneous & Visceral & Neurological & Ocular \\
\hline $\begin{array}{l}\text { Cutaneous } \\
\text { dissemination }\end{array}$ & $\begin{array}{l}\text { Neural } \\
\text { extension }\end{array}$ & $\begin{array}{l}\text { Postherpetic } \\
\text { neuralgia }\end{array}$ & $\begin{array}{l}\text { Loss of corneal } \\
\text { sensation }\end{array}$ \\
\hline $\begin{array}{l}\text { Bacterial } \\
\text { superinfection }\end{array}$ & Bronchitis & $\begin{array}{l}\text { Aseptic } \\
\text { meningitis }\end{array}$ & Panophthalmitis \\
\hline Scarring & Esophagitis & $\begin{array}{l}\text { Meningo- } \\
\text { encephalitis }\end{array}$ & Keratitis \\
\hline Cellulitis & Gastritis & $\begin{array}{l}\text { Transverse } \\
\text { myelitis }\end{array}$ & Scleritis \\
\hline $\begin{array}{l}\text { Zoster } \\
\text { gangrenosum }\end{array}$ & Colitis & $\begin{array}{l}\text { Ascending } \\
\text { myelitis }\end{array}$ & Uveitis \\
\hline & Cystitis & $\begin{array}{l}\text { Peripheral nerve } \\
\text { palsies }\end{array}$ & Chorioretinitis \\
\hline & & Diaphragmatic & \\
\hline
\end{tabular}




\begin{tabular}{|l|l|l|l|}
\hline & Myostitis & paralysis & Iridocyclitis \\
\hline & Pericarditis & $\begin{array}{l}\text { Cranial nerve } \\
\text { palsies }\end{array}$ & Optic neuropathy \\
\hline & Pleuritis & Sensory loss & Ptosis \\
\hline & Peritonitis & Deafness & Mydriasis \\
\hline $\begin{array}{l}\text { Visceral } \\
\text { dissemination }\end{array}$ & $\begin{array}{l}\text { Vestibular } \\
\text { dysfunction }\end{array}$ & Lid scarring \\
\hline & Pneumonia & $\begin{array}{l}\text { Granultomatous } \\
\text { cerebral }\end{array}$ & Secondary glaucoma \\
\hline & Hepatitis & Angiitis & Acute retinal necrosis \\
\hline & Myocarditis & Postherpetic itch & $\begin{array}{l}\text { Progressive outer } \\
\text { retinal necrosis }\end{array}$ \\
\hline & Pericarditis & & \\
\hline & Arthritis & & \\
\hline & & & \\
\hline
\end{tabular}

\section{Treatment of postherpetic neuralgia (PHN) Please see previous comment on size font}

PHN can be difficult to treat. It requires a thorough evaluation of the characteristics of the symptoms and sensory findings, as well as of the extent to which everyday living activities are affected. Since treatments also have side effects, careful counselling with frequent reviews and a willingness to adjust doses is essential. After an appropriate trial of the first-line therapy, it may be necessary to progress to alternative treatments on more than one occasion.

There is evidence that tricyclic antidepressants (TCAs), gabapentinoids, opioids, and topical capsaicin are effective in PHN [59]. Topical lidocaine gel (5\%) or topical lidocaine patch (5\%) also showed efficacy for PHN [59]. A guidance for the use of drugs for PHN is shown in Table 5 [60].

\section{Table 5}

Number needed to treat and number needed to harm for effective treatments for postherpetic neuralgia [60]

\begin{tabular}{|l|l|l|l|l|l|}
\hline $\begin{array}{l}\text { Active } \\
\text { treatment }\end{array}$ & $\begin{array}{l}\text { Number of } \\
\text { patient } \\
\text { episodes }\end{array}$ & $\begin{array}{l}\text { Number } \\
\text { of } \\
\text { studies }\end{array}$ & $\begin{array}{l}\text { NNT } \\
\mathbf{9 5 \%}\end{array}$ & $\begin{array}{l}\text { NNH (95\% } \\
\text { CI) minor } \\
\text { harm }\end{array}$ & $\begin{array}{l}\text { NNH (95\% } \\
\text { CI) major } \\
\text { harm }\end{array}$ \\
\hline & & & & & \\
\hline
\end{tabular}




\begin{tabular}{|c|c|c|c|c|c|}
\hline $\begin{array}{l}\text { Combined } \\
\text { tricyclic } \\
\text { antidepressants }\end{array}$ & 248 & 4 & $\begin{array}{l}2.64 \\
(2.1- \\
3.54)\end{array}$ & $\begin{array}{l}5.67(3.34- \\
18.58)\end{array}$ & $\begin{array}{l}16.9(8.85- \\
178)\end{array}$ \\
\hline $\begin{array}{l}\text { Combined } \\
\text { gabapentin }\end{array}$ & 559 & 3 & $\begin{array}{l}4.39 \\
(3.34- \\
6.07)\end{array}$ & $\begin{array}{l}3.93(2.64- \\
7.66)\end{array}$ & $\begin{array}{l}12.25(7.69- \\
30.2)\end{array}$ \\
\hline $\begin{array}{l}\text { Combined } \\
\text { pregabalin }\end{array}$ & 411 & 3 & $\begin{array}{l}4.93 \\
(3.66- \\
7.58)\end{array}$ & $\begin{array}{l}4.27(2.78- \\
9.18)\end{array}$ & - \\
\hline $\begin{array}{l}\text { Combined } \\
\text { opioids }\end{array}$ & 211 & 2 & $\begin{array}{l}2.67 \\
(2.07- \\
3.77)\end{array}$ & $\begin{array}{l}3.57(2.16- \\
10.23)\end{array}$ & $\begin{array}{l}6.29(4.16- \\
12.8)\end{array}$ \\
\hline Tramadol & 108 & 1 & $\begin{array}{l}4.76 \\
(2.61- \\
26.97)\end{array}$ & - & - \\
\hline $\begin{array}{l}\text { Topical } \\
\text { lidocaine (5\% } \\
\text { patch) }\end{array}$ & 64 & 1 & $\begin{array}{l}2 \\
(1.43- \\
3.31)\end{array}$ & - & - \\
\hline
\end{tabular}

\section{Prevention}

In light of the significant burden caused by $\mathrm{HZ}$ and its complications (mainly PHN), the adoption of a preventive strategy appears to be particularly promising. In this respect, two main forms of prevention can be envisaged:

- Prevention of HZ itself, and thus of its complications, using vaccination in appropriate age groups (primary prevention), Table 6.

- Prevention of complications of HZ (mainly PHN) as soon as the disease has manifested itself by early and aggressive treatment (in essence a form of secondary prevention), although only supported by relatively weak evidence.

\section{Table 6}

Summary of $\mathrm{HZ}$ vaccines (available and/or in development)

\begin{tabular}{|l|l|l|l|l|l|}
\hline Vaccine & Type & Indications & Schedule(s) & $\begin{array}{l}\text { Regulatory } \\
\text { status }\end{array}$ & Notes \\
\hline & & $\begin{array}{l}\text { HZ and } \\
\text { HZ- } \\
\text { associated }\end{array}$ & & & $\begin{array}{l}\text { Contrain } \\
\text { immunoc } \\
\text { individuc }\end{array}$ \\
\hline "Classic" & Live, & & & \\
\hline
\end{tabular}




\begin{tabular}{|c|c|c|c|c|c|}
\hline OkaV & attenuated & $\begin{array}{l}\text { PHN } \\
\text { prevention } \\
\text { in subjects } \\
>50 \mathrm{y} . \mathrm{o}\end{array}$ & 1 dose & Licensed & $\begin{array}{l}\text { Must be k } \\
\left.-15{ }^{\circ} \mathrm{C}\right) \\
\text { reconstitl }\end{array}$ \\
\hline $\begin{array}{l}\text { Refrigerator- } \\
\text { stable OkaV }\end{array}$ & $\begin{array}{l}\text { Live, } \\
\text { attenuated }\end{array}$ & $\begin{array}{l}\text { As for } \\
\text { "Classic" } \\
\text { OkaV }\end{array}$ & 1 dose & Licensed & $\begin{array}{l}\text { Can be st } \\
2 \text { and } 8{ }^{\circ} \\
\text { reconstitl }\end{array}$ \\
\hline $\begin{array}{l}\text { Heat- } \\
\text { inactivated } \\
\text { OkaV }\end{array}$ & Inactivated & N.A & $\begin{array}{l}1,3,4 \\
\text { doses ( } 30 \\
\text { day interval } \\
\text { between } \\
\text { doses) }\end{array}$ & $\begin{array}{l}\text { Not } \\
\text { licensed }\end{array}$ & $\begin{array}{l}\text { Prelimina } \\
\text { various g: } \\
\text { immunoc } \\
\text { individua } \\
\text { mixed res } \\
\text { Immunog } \\
\text { (significa } \\
\text { VZV CM }\end{array}$ \\
\hline $\begin{array}{l}\text { Subunit } \\
\text { vaccine }\end{array}$ & $\begin{array}{l}\text { Recombinant } \\
\text { subunit }(\mathrm{gE}), \\
\text { adjuvanted }\end{array}$ & $\begin{array}{l}\mathrm{HZ} \text { and } \\
\mathrm{HZ}- \\
\text { associated } \\
\text { PHN } \\
\text { prevention } \\
\text { in subjects } \\
>50 \text { y.o. } \\
\text { (proposed } \\
\text { indication) }\end{array}$ & $\begin{array}{l}2 \text { doses (0- } \\
2 \text { months) }\end{array}$ & $\begin{array}{l}\text { Licensed in } \\
\text { USA, } \\
\text { Canada, } \\
\text { European } \\
\text { Union, and } \\
\text { Japan }\end{array}$ & $\begin{array}{l}\text { Based on } \\
\text { VZV glyc } \\
\text { as target } \\
\text { liposome. } \\
\text { adjuvant } \\
\text { (AS01 } 1_{B} \text { ) }\end{array}$ \\
\hline
\end{tabular}

In the following sections, we will focus on the former, given that the latter has been covered in the "Management" section. It is sufficient to highlight here that the early and aggressive treatment option suffers from drawbacks, as alluded to earlier. From a pathophysiological stand point, in many cases, damage has already occurred before treatment initiation; Please delete ; ... and from a "practical"/clinical stand point, the requirement for antiviral treatment to start within $72 \mathrm{~h}$ after $\mathrm{HZ}$ onset to be effective can prove difficult to fulfill in practice.

\section{The live-attenuated Oka vaccine strain of VZV This size font should be used for all following headings}

The currently licensed vaccine is a live-attenuated Oka vaccine strain of VZV $(\mathrm{OkaV})$; in this respect, it is identical to the varicella vaccine, but contains an approximately 14 -fold higher concentration of $\mathrm{OkaV}$ virus than the varicella vaccine $[61,62]$.

The OkaV vaccine has been available both in USA and in the EU since 2006 ; Please delete ; and substantial knowledge on its efficacy, safety, and 
effectiveness has been accumulated. The main outstanding issue with the $\mathrm{OkaV}$ vaccine is related to the fact that it is a live-attenuated vaccine, which, in spite of it being the most attenuated of live viral vaccines [63], is currently contraindicated in immunocompromised individuals (immunodeficient or immunosuppressed), in line with other live-attenuated viral vaccines [61, 62]. This contraindication renders its use in immunocompromised individuals to be problematic. Since, as outlined in the introduction, the immune-endocrine axis is one of the body systems involved in the occurrence of frailty in the elderly, the above contraindication could represent a concern in $\mathrm{HZ}$ prevention in this special population, though it is by no means established that the immune system alterations associated with frailty confer an increased risk of adverse events upon $\mathrm{OkaV}$ vaccine administration [10]. On the other hand, many of the frail elderly also suffer from comorbidities that increase their likelihood of developing $\mathrm{HZ}$ and its attendant complications, and they would benefit from $\mathrm{HZ}$ prevention. The choice of vaccination in the elderly is, therefore, a delicate balancing act between safety and efficacy of vaccines and the risks of developing infectious diseases and their complications [64]. Most available studies of the use of $\mathrm{OkaV}$ vaccine in the elderly with comorbidities and/or varying degrees of immunocompromised conditions have not considered explicitly frailty criteria in the selection of the sample, although their findings could be applied with caution to the frail elderly who share many of the same conditions.

AQ3

In a very recent study, however, the immunogenicity of $\mathrm{OkaV}$ vaccine and immunologic markers of VZV-specific T-cell-mediated immunity (as an interferon-gamma ELISPOT assay) associated with a response to OkaV vaccine and cellular markers of immune senescence were evaluated specifically in the frail elderly. The study was performed in a cohort of 190 frail nursing home residents with a mean age of 89 years (range 80-102 years) and at least one comorbidity, and in a cohort of 50 community-dwelling seniors, used as a comparison group, with a mean age of 67 years (range 60-75 years) and a maximum of one comorbidity. Frailty was assessed with a validated 70 -item (variables) frailty index score based on the cumulative deficit model, and calculated as the ratio between the number of deficits and the total number of items. The two groups were given $\mathrm{OkaV}$ vaccine and had blood samples taken at the same visit the vaccine was administered and 6 weeks later. Results showed that, as foreseen, the frail elderly exhibited higher levels of immunosenescence at baseline, but interestingly, they were still able to respond 
to $\mathrm{OkaV}$ vaccine by mounting potentially protective responses. Clearly, as acknowledged by the authors, a limitation of the study is the limited time frame and the lack of direct information on protective clinical efficacy [65].

Another outstanding issue with the $\mathrm{OkaV}$ vaccine is related to the duration of protection, which has been shown to wane over time and which has not been established beyond 5 year postvaccination [62].

\section{Other vaccines derived from the Oka vaccine strain of VZV}

Heat-inactivated Zoster vaccine Please use the same font size as the previous heading

To have a vaccine that could be safely administered to immune compromised individuals, attempts have been made to develop a heat-inactivated OkaV zoster vaccine. Some trials have been performed in different groups of immune compromised individuals, with mixed results but, at the time of writing, the heat-inactivated vaccine has not been licensed [66, 67, 68].

\section{Adjuvanted VZV subunit vaccine}

The sequencing of the VZV genome and the identification of the role of specific genes encoding specific viral components and of their function has made it possible to select candidates suitable for inclusion in a vaccine. The development of an adjuvanted VZV subunit vaccine, named Adjuvanted Recombinant Zoster Vaccine (RZV), therefore, represents a new approach to the problem of varicella and HZ prevention [63].

The RZV is based, on one hand, on the recombinant VZV glycoprotein $\mathrm{E}$ as the target epitope and, on the other hand, on a liposome-based adjuvant system $\left(\mathrm{AS} 01_{\mathrm{B}}\right)$. Studies have shown that a two-dose schedule can induce robust VZVspecific T-cell responses that last for at least 6 years after vaccination [63].

Two international phase III randomized, double-blind, placebo-controlled clinical trials were conducted concurrently at the same study sites and using the same methods to assess the efficacy and safety of RZV in preventing HZ in two different populations. The ZOE-50 study (NCT01165177) included adults $\geq$ 50 years of age [69] and ZOE-70 (NCT01165229) included adults $\geq 70$ years of age [70]. In the ZOE-50 study, the incidence of HZ was $0.3 / 1,000$ person-years (PY) in the RZV group and 9.1/1,000 PY in the placebo group with an estimated overall vaccine efficacy (VE) in preventing $\mathrm{HZ}$ of $97.2 \%$ [69]. In a pooled 
analysis of over 70 years old from both ZOE 50 and ZOE-70, the HZ incidence in the RZV group was $0.9 / 1,000 \mathrm{PY}$ and $9.2 / 1,000$ in the placebo group ; Please delete; and the estimated overall VE against $\mathrm{HZ}$ was $91.3 \%$ [70].

If adult $\mathrm{HZ}$ vaccination was to be globally adopted, it could lead to a dramatic reduction in the incidence of PHN. Combining this with the long-term effect $(40+$ years $)$ of childhood varicella vaccination, future generations might be largely immune to PHN.

According to available information, the protection is maintained for up to 4 year postvaccination and the duration of protection beyond 4 years is under investigation [71].

The vaccine has first been approved in Canada and in the United States, and more recently in Japan and in the European Union [72].

\section{Conclusions}

The concept of frailty has become an important tool in geriatric practice but, as is often the case with the elderly population, specific clinical studies are very few or unavailable. In the case of $\mathrm{HZ}$ prevention, to our knowledge, only two published studies were performed in a population of nursing home residents. It is very often the case that treatment (and prevention) decisions have to be extrapolated from data collected in other population groups, which requires caution given the propensity of the frail elderly to experience more frequent and more severe adverse effects to treatment, with outcomes that can lead to worsening degrees of frailty and higher mortality. Though not easy to perform, further research would be needed in this special and numerically growing population.

\section{Funding}

No funding was received.

\section{Compliance with Ethical Standards}

Conflict of interest Ermanno Zorzoli Congress attendance sponsored by Sanofi. Francesca Pica has no conflict of interest. Giulia Masetti has no conflict of interest. Elisabetta Franco scientific collaboration with GSK, Merck, Pfizer, and Sanofi. Reimbursement for participation to Meetings and Advisory Board without personal fees. Antonio Volpi Clinical trial for GSK and Achaogen. 
Advisory board meetings for GSK and Sanofi Pasteur MSD. Giovanni Gabutti has received grants from GlaxoSmithKline Biologicals SA, Sanofi Pasteur MSD, Novartis,Crucell/Janssen, Seqirus, Sanofi Pasteur, Merck Italy, and Pfizer for being consultant or taking part in advisory board, expert meetings, being a speaker or an organizer of congresses/conferences, and acting as investigator in clinical trials.

AQ4

Human and animal rights This article does not contain any studies with human participants or animals performed by any of the authors.

Informed consent For this type of study, formal consent is not required.

\section{References}

1. United Nations, Department of Economic and Social Affairs, Population Division (2017) World population prospects: The 2017 revision, key findings and advance tables. Working paper no. ESA/P/WP/248.

https://esa.un.org/unpd/wpp/Publications/Files/WPP2017_KeyFindings.pdf. Accessed 10 July 2017

2. Fried LP, Ferrucci L, Darer J et al. (2004) Untangling the concepts of disability, frailty, and comorbidity: implications for improved targeting and care. J Gerontol A Biol Sci Med Sci 59:255-263

3. Fried LP, Tangen CM, Walston J et al (2001) Cardiovascular Health Study Collaborative Research Group. Frailty in older adults: evidence for a phenotype. J Gerontol A Biol Sci Med Sci 56:M146-56

4. Rockwood K, Song X, MacKnight C et al (2005) A global clinical measure of fitness and frailty in elderly people. CMAJ 173:489-495

5. Fit for Frailty consensus best practice guidance for the care of older people living in community and outpatient settings - a report from the British Geriatrics Society 2014

$\mathrm{AQ5}$

6. Rockwood K, Mitnitski A, MacKnight C (2002) Some mathematical models of frailty and their clinical implications. Rev Clin Gerontol 12:109- 
7. Gobbens RJ, Luijkx KG, Wijnen-Sponselee MT et al. (2010) In search of an integral conceptual definition of frailty: opinions of experts. J Am Med Dir Assoc 11:338-343

8. Clegg A, Young J, Iliffe S et al. (2013) Frailty in elderly people. Lancet $381868: 752-762$

9. Wilson D, Jackson T, Sapey E et al. (2017) Frailty and sarcopenia: the potential role of an aged immune system. Ageing Res Rev 36:1-10

10. Baylis D, Bartlett DB, Syddall HE et al (2013) Immune-endocrine biomarkers as predictors of frailty and mortality: a 10-year longitudinal study in community-dwelling older people. Age (Dordr) 35:963-971

11. Wang GC, Casolaro V (2014) Immunologic changes in frail older adults. Trans1 Med UniSa 24:1-6

12. Caruso C, Buffa S, Candore G et al (2009) Mechanisms of immunosenescence. Immun Ageing 6:10

13. Cohen JI (2014) Introduction to Herpesviridae. In: Mandell GL, Bennett JE, Dolin R (eds) Mandell, Douglas, and Bennett's principles and practice of infectious diseases, 8th edn. Elsevier, Philadelphia

14. Wang GC, Han C, Detrick B et al (2016) Herpesvirus infections and risk of frailty and mortality in older women: Women's Health and Aging Studies. J Am Geriatr Soc 64:998-1005

15. Haeseker MB, Pijpers E, Dukers-Muijrers NH et al (2013) Association of cytomegalovirus and other pathogens with frailty and diabetes mellitus, but not with cardiovascular disease and mortality in psycho-geriatric patients; a prospective cohort study. Immun Ageing 10:30

16. Goldeck D, Pawelec G, Norman K et al (2016) No strong correlations between serum cytokine levels, CMV serostatus and hand-grip strength in older subjects in the Berlin BASE-II cohort. Biogerontology 17:189-198 
17. Levin MJ (2012) Immune senescence and vaccines to prevent herpes zoster in older persons. Curr Opin Immunol 24:494-500

18. Weinberg A, Zhang JH, Oxman MN et al (2009) US Department of Veterans Affairs (VA) Cooperative Studies Program Shingles Prevention Study Investigators. Varicella-zoster virus-specific immune responses to herpes zoster in elderly participants in a trial of a clinically effective zoster vaccine. J Infect Dis 200:1068-1077

19. SAGE Working Group on Varicella and Herpes Zoster Vaccines. Background paper on Herpes zoster vaccines. 2014 Mar. http://www.who.int/immunization/sage/meetings/2014/april/2_Background_docun ua $=1$. Accessed 10 July 2017

20. Franco E, Zorzoli E, Valente $\mathrm{N}$ et al. (2016) Aspetti epidemiologici dell'Herpes zoster e della nevralgia post-erpetica [Epidemiological aspects of Herpes zoster and post-herpetic neuralgia]. In: Gabutti G (ed) Herpes zoster e nevralgia post-erpetica. Edizioni Minerva medica, Torino, pp 17-26 (Italian)

21. Varghese L, Standaert B, Olivieri A et al. (2017) The temporal impact of aging on the burden of herpes zoster. BMC Geriatr 17:30

22. Maggi S, Gabutti G, Franco E et al (2015) Preventing and managing herpes zoster: key actions to foster healthy aging. Aging Clin Exp Res 27:511

23. WHO. Active ageing: a policy framework. WHO/NMH/NPH/02.8. 2002.

http://apps.who.int/iris/bitstream/10665/67215/1/WHO_NMH_NPH_02.8.pdf. Accessed 10 July 2017

24. Gabutti G, Bonanni P, Conversano M et al (2017) Prevention of Herpes Zoster and its complications: from clinical evidence to real life experience. Hum Vaccin Immunother 13:391-398

25. Stefanati A, Kuhdari P, Bertoni L et al. (2016) Storia naturale e risposta immunitaria nell'infezione da Varicella-zoster virus: varicella ed Herpes zoster [Natural history and immune response in Varicella-zoster virus 
infection: varicella and herpes zoster]. In: Gabutti G (ed) Herpes zoster e nevralgia post-erpetica. Edizioni Minerva medica, Torino, pp 9-16 Italian.

26. Dworkin RH, Schmader KE (2001) The epidemiology and natural history of herpes zoster and post-herpetic neuralgia. In: Watson CP, Gershon AA (eds) Herpes zoster and post-herpetic neuralgia, 2nd edn. Elsevier Press, New York, pp 39-64

27. Gershon AA, Gershon MD, Breuer J et al (2010) Advances in the understanding of the pathogenesis and epidemiology of herpes zoster. J Clin Virol 48:S2-S7

28. Opstelten W, Mauritz JW, de Wit NJ, et al (2002) Herpes zoster and postherpetic neuralgia: incidence and risk indicators using a general practice research database. Fam Pract 19:471-475

29. Cohen JI (2013) Clinical practice: Herpes zoster. N Engl J Med $369: 255-263$

30. Bricout H, Perinetti E, Marchettini P et al (2014) Burden of herpes zoster-associated chronic pain in Italian patients aged 50 years and over (2009-2010): a GP-based prospective cohort study. BMC Infect Dis 14:637

31. Kawai K, Gebremeskel BG, Acosta CJ (2014) Systematic review of incidence and complications of herpes zoster: towards a global perspective. BMJ Open 4:e004833

32. Jung BF, Johnson RW, Griffin DRJ, et al (2004) Risk factors for postherpetic neuralgia in patients with herpes zoster. Neurology 62:15451551

33. Volpi A, Gatti A, Serafini G et al (2007) Clinical and psychosocial correlates of acute pain in herpes zoster. J Clin Virol 38:275-279

34. Volpi A, Gatti A, Pica F et al (2008) Clinical and psychosocial correlates of post-herpetic neuralgia. J Med Virol 80:1646-1652

35. Gatti A, Pica F, Boccia MT et al (2010) No evidence of family history as a risk factor for herpes zoster in patients with post-herpetic neuralgia. J Med 
36. Pica F, Gatti A, Divizia M et al (2014) One-year follow-up of patients with long-lasting post-herpetic neuralgia. BMC Infect Dis 14:556

37. Johnson RW, Bouhassira D, Kassianos G et al. (2010) The impact of herpes zoster and post-herpetic neuralgia on quality-of-life. BMC Med 8:37

38. WHO (2014) Varicella and herpes zoster vaccines: WHO position paper, June 2014. Wkly Epidemiol Rec 89:265-288 (English, French)

39. Johnson RW, Wasner G, Saddier P et al (2008) Herpes Zoster and postherpetic neuralgia: optimizing management in the elderly patient. Drugs Aging 25:991-1006

40. Pinchinat S, Cebrián-Cuenca AM, Bricout H et al (2013) Similar herpes zoster incidence across Europe: results from a systematic literature review. BMC Infect Dis 13:170

41. Sato K, Adachi K, Nakamura H et al (2017) Burden of herpes zoster and postherpetic neuralgia in Japanese adults 60 years of age or older: Results from an observational, prospective, physician practice-based cohort study. J Dermatol 44:414-422

42. Alicino C, Trucchi C, Paganino C et al (2017) Incidence of herpes zoster and post-herpetic neuralgia in Italy: Results from a 3-years population-based study. Hum Vaccin Immunother 13:399-404

43. Gialloreti LE, Merito M, Pezzotti P et al (2010) Epidemiology and economic burden of herpes zoster and post-herpetic neuralgia in Italy: a retrospective, population-based study. BMC Infect Dis 10:230

44. Torcel-Pagnon L, Bricout H, Bertrand I et al (2017) Impact of underlying conditions on Zoster-related pain and on quality of life following Zoster. J Gerontol A Biol Sci Med Sci 72:1091-1097

45. Nagel MA, Jones D, Wyborny A (2017) Varicella zoster virus vasculopathy: The expanding clinical spectrum and pathogenesis. $\mathrm{J}$ Neuroimmunol 308:112-117 
46. Marra F, Ruckenstein J, Richardson K (2017) A meta-analysis of stroke risk following herpes zoster infection. BMC Infect Dis 17:198

47. Gater A, Uhart M, McCool R et al. 2015) The humanistic, economic and societal burden of herpes zoster in Europe: a critical review. BMC Public Health 15:193

48. Lukas K, Edte A, Bertrand I (2012) The impact of herpes zoster and post-herpetic neuralgia on quality of life: patient-reported outcomes in six European countries. Z Gesundh Wiss 20:441-451

49. Jackson LA, Reynolds MA, Harpaz R (2008) Hospitalizations to treat herpes zoster in older adults: causes and validated rates. Clin Infect Dis 47:754-759

50. Panatto D, Bragazzi NL, Rizzitelli E et al (2015) Evaluation of the economic burden of Herpes Zoster (HZ) infection. Hum Vaccin Immunother $11: 245-262$

51. Hobbelen PH, Stowe J, Amirthalingam G et al. (2016) The burden of hospitalisation for varicella and herpes zoster in England from 2004 to 2013. J Infect 73:241-253

52. Valente N, Cocchio S, Stefanati A et al (2017) Temporal trends in herpes zoster-related hospitalizations in Italy, 2001-2013: differences between regions that have or have not implemented varicella vaccination. Aging Clin Exp Res 29:771-779

53. Schmader K (2016) Herpes zoster. Clin Geriatr Med 32:539-553

54. Kaye AD, Baluch A, Scott JT (2010) Pain management in the elderly population: a review. Ochsner J 10:179-187

55. Gnann J (2006) Antiviral therapy for herpes zoster. Herpes 13:16A-20A

56. Volpi A (2007) Severe complications of herpes zoster. Herpes 14 :35-39

57. di Luzio PU, Arpinelli F, Visonà G (1999) Herpes zoster and its complications in Italy: an observational survey. J Infect 38:116-120 
58. Oxman MN (2000) Clinical manifestations of herpes zoster. In: Arvin AM, Gershon AA (ed) Varicella-zoster virus: virology and clinical management. Cambridge University Press, Cambridge, pp 246-275

59. Haanpää M, Rice ASC, Rowbotham MC (2015) Treating herpes zoster and postherpetic neuralgia. PAIN Clin Updates 23:1-8 AQ6

60. Hempenstall K, Nurmikko TJ, Johnson RW et al. (2005) Analgesic therapy in postherpetic neuralgia: a quantitative systematic review. PLoS Med 2:e164

61. VARIVAX Summary of Product Characteristics. https://www.medicines.org.uk/emc/medicine/15264. Accessed 12 July 2017

62. ZOSTAVAX Summary of Product Characteristics. http://www.ema.europa.eu/docs/en_GB/document_library/EPAR__Product_Information/human/000674/WC500053462.pdf. Accessed 12 July 2017

63. Watson CPN et al (2017) Herpes zoster: postherpetic neuralgia and other complications. Springer, Switzerland

64. Amanna IJ (2012) Balancing the Efficacy and Safety of vaccines in the elderly. Open Longev Sci 6:64-72

65. Lelic A, Verschoor CP, Lau VW et al (2016) Immunogenicity of varicella vaccine and immunologic predictors of response in a cohort of elderly nursing home residents. J Infect Dis 214:1905-1910

66. Redman RL, Nader S, Zerboni L et al (1997) Early reconstitution of immunity and decreased severity of herpes zoster in bone marrow transplant recipients immunized with inactivated varicella vaccine. J Infect Dis 176:578-585

67. Hata A, Asanuma H, Rinki M et al (2002) Use of an inactivated varicella vaccine in recipients of hematopoietic-cell transplants. N Engl J Med 347:26-34 
68. Mullane KM, Winston DJ, Wertheim MS et al (2013) Safety and immunogenicity of heat-treated zoster vaccine (ZVHT) in immunocompromised adults. J Infect Dis 208:1375-1385

69. Lal H, Cunningham AL, Godeaux O et al (2015) Efficacy of an adjuvanted herpes zoster subunit vaccine in older adults. N Eng J Med 372:2087-2096

70. Cunningham AL, Lal H, Kovac M et al (2016) Impact of the herpes zoster subunit vaccine in adults 70 years of age or older. N Eng J Med 375:1019-1032

71. SHINGRIX Product Monograph (Approved 13 October 2017). https://pdf.hres.ca/dpd_pm/00041658.PDF Accessed 20 Dec 2017

72. European Commission (2018) Community register of medicinal products for human use. http://ec.europa.eu/health/documents/communityregister/html/h1272.htm\#EndOfPage Accessed 26 Mar 2018 